https://helda.helsinki.fi

\title{
House dust microbiome and human health risks
}

\section{Shan, Yifan}

2019-09

Shan , Y , Wu , W , Fan , W , Haahtela , T \& Zhang , G 2019 , ' House dust microbiome and human health risks ' , International Microbiology , vol. 22 , no. 3 , pp. 297-304 . https://doi.org/10.1007/s10123-019-0

http://hdl.handle.net/10138/320950

https://doi.org/10.1007/s10123-019-00057-5

publishedVersion

Downloaded from Helda, University of Helsinki institutional repository.

This is an electronic reprint of the original article.

This reprint may differ from the original in pagination and typographic detail.

Please cite the original version. 


\title{
House dust microbiome and human health risks
}

\author{
Yifan Shan ${ }^{1} \cdot$ Weidong $\mathrm{Wu}^{1} \cdot$ Wei Fan ${ }^{1} \cdot$ Tari Haahtela $^{2} \cdot{\text { Guicheng } \text { Zhang }^{3}}^{3}$ \\ Received: 24 October 2018 / Revised: 3 January 2019 / Accepted: 3 January 2019 / Published online: 14 January 2019 \\ (C) Springer Nature Switzerland AG 2019
}

\begin{abstract}
People spend a lot of time indoors and the indoor microbiome is a major part of the environment that we are exposed to. However, awareness of the exposure to the indoor microbiome and its health effects remains poor. Outdoor environment (soil and air), indoor sources (ventilation, dampness and building materials), human occupants, and pets compose the indoor microbial community. It has been estimated that up to 500-1000 different species can be present in house dust. House dust is a major source and reservoir of indoor microbiome, which influences human microbiome and determines health and disease. Herein, we review the origins and the components of the fungal and bacterial communities in house dust and their possible effect on human health, in particular on allergic disorders, intestinal microbiome, and immune responses. We expect to lay a solid foundation for the further study on the mechanisms of how the house dust microbes interact with the host microbiome and the human immune system.
\end{abstract}

Keywords House dust microbiome $\cdot$ Fungal community $\cdot$ Bacterial community $\cdot$ Allergic diseases $\cdot$ Gut microbiome

In urban environments, humans spend even $90 \%$ of their time indoors and are exposed to a wide range of microbial taxa present in house dust. Reduced contact with biodiversity associated with the environmental microbiome from soil and air may adversely affect human health and increase, e.g., the allergy risk (Hanski et al. 2012).

Outdoor environment (soil and air), indoor sources (ventilation, dampness, and building materials), human occupants, and pets compose the indoor microbial community. It has been estimated that up to 500-1000 different species can be present in house dust (Rintala et al. 2012). Indoor fungal communities are mainly influenced by the outdoor environment, while indoor bacteria are more likely affected by occupants, pets, and ventilation methods (Barberan et al. 2015a; Meadow et al. 2014). A strong geographic pattern has been reported for indoor fungal communities (Amend et al. 2010), which are also influenced by the season (Nevalainen et al. 2015; Pitkaranta

Weidong $\mathrm{Wu}$

wdwu2013@126.com

1 School of Public Health, Xinxiang Medical University, 601 Jinsui Street, Xinxiang 453003, Henan Province, People's Republic of China

2 Skin and Allergy Hospital, Helsinki University Central Hospital, Helsinki, Finland

3 School of Public Health, Curtin University, Perth, Australia et al. 2008). Household residents have a strong and homogenizing effect on the indoor bacterial community (Taubel et al. 2009). Non-human occupants, including dogs and household insects, influence the indoor dust microbiota significantly (Fujimura et al. 2010; Gliniewicz et al. 2003). However, at the microbial level, we do not fully understand those factors and forces shaping the indoor microbial communities.

With the advent of sequencing technology, many studies have recently focused on the relation of both environmental and host microbiome with human health. We review the origins of the fungal and bacterial community in house dust and its possible effect on human health, in particular on allergic disorders, intestinal microbiome, and immune responses.

\section{Microbiota in House Dust}

"House dust" is the main reservoir of microbial taxa in the domestic environment and includes particulate matter from soil and plants as well as human and animal skin and excretions that collect on horizontal surfaces (Macher 2001). The amount and diversity of the microbiome in dust affect health, especially because dust-born microbes and their products suspend into the air and produce a significant indoor exposure by breathing. Resuspension from floor dust contributes to both the bacterial and fungal indoor air concentration (Hospodsky et al. 2012, 2015). 
Indoor dust ingredients from fungal sources may include intact fungal conidia (like Alternaria and Helminthosporium), intact fungal spores (like Aspergillus, Penicillium), and spore fragments with different sizes (Rintala et al. 2012). These fungal conidia and spores that may carry kinds of compounds, such as ergosterol and (1-3)- $\beta$-D-glucan common in all fungi; nonvolatile metabolic products like mycotoxins and volatile compounds pose a threat to human health (Korpi et al. 1997). Bacterial components in dust are mainly dead and living cells, smaller fragments of degraded cells, and endospore and other spores (Rintala et al. 2012). Dust is the abundant source of spore-bearing organism, especially the dust laid undisturbed for long periods of time in the high shelves, mainly including Bacillus prausnitzii, Bacillus mesentericus, Bacillus ruminates, Bacillus panis, and Bacillus adhaerens (Laubach 1916).

\section{Fungi}

Dust fungal communities have traditionally been determined using standard medium cultivation methods. Mattress dust collected from 130 houses contained the number of mold counts with an extreme value of more than 70,000,000 CFU/ $\mathrm{g}$ of dust (Beguin 1995). Aureobasidium pullulans, Alternaria alternata, Penicillium chrysogenum, Aspergillus penicilloides, and Aspergillus restrictus were the main species and Eurotium repens was the most frequent species (Beguin 1995). Besides these filamentous fungi, there are also yeasts, such as Candida, Cryptococcus, Rhodotorula, Saccharomyces, and Sporobolomyces, and sterile isolates including both ascomycetous and basidiomycetous colonies. The fungal communities in mattress dust are more numerous in winter, especially in December and January (Beguin 1995). Dust collected from 100 carpets in various indoor environments inhabited by atopic individuals (living room/bedroom, school classroom, office) showed that Eurotium repens, Penicillium chrysogenum, Alternaria alternata, Aureobasidium pullulans, and Phoma herbarum were the main species (Beguin and Nolard 1996). Another study analyzed floor dust samples collected from 175 houses from children that were either sensitized to house dust mites $(n=61)$ or other aeroallergens $(n=57)$, or non-atopic $(n=57)$. They found Penicillium, Alternaria, and Cladosporium to be the three most common fungi (Wickman et al. 1992).

Using culture-independent methods, house dust samples collected from 72 buildings across six continents indicated that the most cosmopolitan taxa (such as Alternaria, Cladosporium, and Epicoccum) are common everywhere and some dominant taxa, like Eurotiomycetes, Sordariomycetes, Zygomycota. It also showed that the latitude of the location influences the indoor fungal composition. Analysis of the operational taxonomic unit (OTU) distribution showed that the fungal diversity is higher in temperate climate zones compared with tropical zones (Amend et al. 2010). Another study explored the indoor microbial communities in high surface dust and filter dust using a culture-independent approach. They found that the Dothideomycetes class is predominant in high surface dust, while Agaricomycetes and Sordariomycetes are dominant in filter dust (Noris et al. 2011). Pitkaranta et al. (2008) also found that the most dominant species of the fungal flora in indoor dust were members of the class Dothideomycetes. In addition, a gradual increase in fungal diversity was observed from winter, through spring, and summer to fall, suggesting that the outdoor environment is the main source of these fungal communities as their amplification and diversification are in line with the seasonal succession (Pitkaranta et al. 2008). Furthermore, the fungal concentration in house dust is generally higher in hot seasons than in cool seasons while air conditioning and heating (used in summer and winter) also have an effect on the concentration of fungi in house dust (Yamamoto et al. 2011).

\section{Bacteria}

Gram-positive bacteria dominate in house dust and the most common genera are Deinococcus, Firmicutes Bacillus, Enterococcus, Lactococcus, Staphylococcus, and Actinobacteria Arthrobacter, Corynebacterium, Micrococcus, Nocardiopsis, Rhodococcus, and Streptomyces (Andersson et al. 1999). A substantial number of mattress dust samples from farm children's beds contain Listeria monocytogenes (Korthals et al. 2008). Mycobacteria were shown to be abundant and diverse in house dust collected from vacuum cleaner dust bags (Torvinen et al. 2010).

Several other studies (Hanson et al. 2016; Noris et al. 2011; Rintala et al. 2008; Taubel et al. 2009) also revealed that the house dust bacterial community is dominated by Grampositive bacteria, especially Firmicutes and Actinobacteria. However, another study found that in house dust, a higher number of plant-associated species Actinobacteria were more prevalent than Firmicutes (Pakarinen et al. 2008). Furthermore, some bacteria in this house dust were of Gramnegative origin. Bouillard et al. found that Gram-negative species account for one third of the total bacteria from air, dust, and surface samples, and Pantoea, Stenotrophomonas maltophilia, and Pseudomonas putida were the most abundant taxa (Bouillard et al. 2005). Rintala et al. detected that about $40 \%$ of OTUs in house dust samples belonged to Gramnegative bacteria of four dominant families Sphingomonadaceae, Xanthomonadaceae, Oxalobacteraceae, and Rhizobiaceae (Rintala et al. 2008). Other studies showed the importance of human-associated sources on dust bacterial communities, and the bacterial diversity in dust is related to the number of inhabitants (Dannemiller et al. 2016). A house with more than three occupants had a higher bacterial diversity than a house with fewer occupants (Weikl et al. 2016). 


\section{Environmental Factors Affecting the House Dust Microbiome}

\section{Living Conditions}

Water availability is a major factor for microbial growth (Ayerst 1969). For example, indoor water leakage is significantly associated with fungal diversity, and mold growth can further modify the effect of the moisture on the fungal richness (Dannemiller et al. 2014; Pitkaranta et al. 2011). Culturebased studies have shown that the growth of fungal species in dust depends on the equilibrium of relative humidity (ERH) conditions (Andersen et al. 2011). Culture-independent methods also demonstrated that ERH is an important parameter for microbial growth as different ERH levels were linked to the richness and evenness of the microbial communities in floor dust (Dannemiller et al. 2017). Also, ventilation is significantly associated with fungal diversity, which is lower in late summer compared to the rest of the year (Weikl et al. 2016). Further, a molecular sequencing study revealed that the microbial communities are less diverse in mechanically ventilated rooms compared to window-ventilated rooms (Kembel et al. 2012).

\section{Level of Urbanization}

Houses in urbanized areas show a homogenization of indoor dust-associated microbiome communities. This may be due to the homogenization of environmental conditions and land use or due to the homogenization of plant communities and other sources of fungi and bacteria (Barberan et al. 2015b; Mckinney 2006). Yet, urbanized areas have a higher plant species richness than rural areas (Ege et al. 2011), while some studies show that more urbanized areas have a lower microbial diversity and higher allergy rates compared to rural areas, which may explain the geographic differences in allergy prevalence (Ege et al. 2011; Hanski et al. 2012).

Recent studies have shown that components of the bacterial communities in house dust are associated with the levels of urbanization with less bacterial richness in urban houses, this is not the case for the fungal communities (Dannemiller et al. 2016). Indoor fungal communities were associated with the story of the house, the greenery around the house, and the concentration of air particulate matter (Weikl et al. 2016).

\section{Season}

The seasonality has a large influence on the fungal communities (Adams et al. 2013; Nevalainen et al. 2015; Pitkaranta et al. 2008) but less so on the bacterial ones (Adams et al. 2014; Barberan et al. 2015a; Moschandreas et al. 2003; Rintala et al. 2008). Indoor fungi originate largely from taxa in the outdoor environment while indoor bacteria more likely originate from occupants, explaining the lower seasonality of the bacterial community (Adams et al. 2014). However, seasonal variations of indoor bacterial communities have also been reported (Moschandreas et al. 2003; Rintala et al. 2008). The microbial concentrations of two types of house dust, rug dust and vacuum cleaner bag dust, changed for different seasons while measured in the same home (Kaarakainen et al. 2009). Rintala et al. examined the indoor dust bacterial community from two buildings and found that the bacterial flora varied significantly between seasons except spring and the difference between the buildings was larger than the difference between seasons (Rintala et al. 2008). In winter, when snow covers the earth, outdoor microbial concentrations are lower than those in other seasons and the occupant-originating microbes dominate the dust microbial community (Rintala et al. 2012).

\section{House Dust Microbiome in Human Health and Disease}

Most of the studies on the microbiome of house dust have focused on microbial taxa that are associated with human health. For instance, Bacteroides are found in indoor dust and Bacteroides fragilis can suppress anti-microbial immune responses during gut colonization (Hanson et al. 2016; Round et al. 2011). Faecalibacterium prausnitzii in the Firmicutes is anti-inflammatory and protective against Crohn's disease and is found to be associated with the number of occupants in the household (Dannemiller et al. 2016; Sokol et al. 2008). Lactobacillus and Acinetobacter spp. can protect against allergies and both are more common in families with more occupants (Chen et al. 2010; Debarry et al. 2010; Ege et al. 2012). In addition, Lactobacillus johnsonii can be protective against allergies and is associated with the presence of dogs (Fujimura et al. 2014).

\section{House Dust Microbiome and Asthma and Allergy}

Exposure to Aspergillus, Penicillium, Cladosporium, Ulocladium, Acremonium, Aureobasidium, Epicoccum, Scopulariopsis, Trichoderma, Alternaria, and Wallemia species may increase the respiratory symptoms for asthmatic patients who live in houses with increased fungal concentrations (Sharpe et al. 2015). Children living in houses with mold exposure have a close to $50 \%$ increased risk of developing allergic rhinitis (Jaakkola et al. 2010), and working in damp and moldy environments may induce asthma (Karvala et al. 2010). However, exposure to reduced richness of fungal and bacterial communities in house dust in early life can increase the risk of developing asthma in later life (Dannemiller et al. 2014; Ege et al. 2011). For example, a low richness of the fungal genera Cryptococcus and skin-associated 
Gammaproteobacteria in house dust has been reported to be related to increased asthma risk (Dannemiller et al. 2014; Hanski et al. 2012).

A cross-sectional survey on allergic diseases and environmental factors by questionnaire and skin-prick test showed that children living on farms and in regular contact with livestock have less hay fever, asthma, and allergic sensitization than children from a non-farming environment. The main speculation is that the development of immune tolerance (stimulation of Th1 cells and suppression of Th2 cells) is stimulated when farm children are exposed to increased microbial antigens (Riedler et al. 2000). Another study on the exposure to environmental microorganisms showed that children who live on farms have a lower prevalence of asthma and atopy compared with children living in the same region but not on a farm (Ege et al. 2011). It was speculated that a rich environmental microbial exposure activates several signaling pathways of Toll-like receptors inducing regulatory $\mathrm{T}$ cells, which improve immune balance and lessen asthma risk (Ege et al. 2011). When comparing urban house dust (low bacterial diversity) to barn dust (high bacterial diversity), the latter directed monocyte-derived human dendritic cells towards Th1 response and away from allergy (Alenius et al. 2009). This supports the hygiene hypothesis that exposure to a rich microbiome in early life prevents developing disease later in life (Rook et al. 2003; Strachan 1989). Other studies also showed that growing up on a farm or exposure to dogassociated house dust can protect against asthma (Fujimura et al. 2014; Riedler et al. 2001). In our study of Karelia (Khoo et al. 2016; Pakarinen et al. 2008), major microbial disparities were found between the Finnish and Russian house dusts (Pakarinen et al. 2008). The higher bacterial content and the predominance of Gram-positive bacteria in Russian dust may have protected the Russian children from allergy (Pakarinen et al. 2008). In Finnish Karelia, exposure to relatively low levels of microbial components in dust reduced the risk of atopy among children and a heavy exposure reduced the risk by $80 \%$ (Von et al. 2010).

House dust contains microbial cell wall components, like bacterial endotoxin associated with Gram-negative bacteria and cell wall component (1-3)- $\beta$-D-glucan of fungi and some bacteria (Adhikari et al. 2014; Douwes et al. 2000; Iossifova et al. 2007; Rylander and Holt 1998). Human exposure to endotoxin was inversely related to the frequency of atopic asthma, hay fever, and allergic sensitization (BraunFahrlander et al. 2002; Eder and von Mutius 2004). However, high exposure to (1-3)- $\beta$-D-glucan in occupational dust was associated with respiratory symptoms, airway inflammation, and decreased lung function (Heldal et al. 2003; Thorn 2001). In rare cases, similar symptoms occurred in the domestic environment when adults were exposed to elevated indoor (1-3)- $\beta$-D-glucan concentrations (Wouters et al. 2002).

\section{House Dust Microbiome and Gut Microbiome}

The most common genera in house dust that are associated with the human gut microbiome are Corynebacterium, Propionibacterium, Streptococcus, Staphylococcus, Lactococcus, Peptostreptococcus, and Lactobacillus species (Rintala et al. 2012, 2008; Taubel et al. 2009). Environmental conditions (diet, host environment including exposure to house dust, and other contributing factors) play an important role in shaping the human gut microbiome (Spor et al. 2011). Although some microorganisms found in soil and untreated food/water do not colonize the host body, they do pass in large quantities through the gut and provide essential services for gut microbiota (Raison et al. 2010). Thus exposure to soil, house dust, and decaying plants can impact the diversity and composition of gut microbiota. An animal study showed that the gut microbiota of lactating piglets that were exposed to soil was enriched in Bacteroidetes and Ruminococcaceae (Vo et al. 2017). A high-throughput sequencing method study found that exposure of BALB/c mice to three different environment conditions (specific pathogenfree animal room, general animal room, and farm house) gave each group its own specific gut microbiota structure. The $\mathrm{BALB} / \mathrm{c}$ mice in the general animal room and farm house than that in the specific pathogen-free animal room had a more abundant gut microbial community, especially for the Bacteroidetes (Zhou et al. 2016). Fujimura et al. (2014) used murine models and also showed that oral gavage of house dust had an effect on the composition of the gastrointestinal microbiota. Moreover, the levels of exposure impacted the composition of gastrointestinal microbiota. We speculate that such modulation of the gut microbiota can also occur in children and that indoor dust exposure may play an important role in the formation of the gut microbiome in early life.

\section{House Dust Microbiome Stimulates the Host Immune System}

Though there is no direct evidence for a relation between the house dust microbiome and the host immune system, some studies have shown that exposure to dust may involve exposure to common allergens or pathogens and cause inflammation, leading to a complex interaction between the adaptive and innate immune system (Rylander and Holt 1998). An animal study showed that mice, living in a specific pathogen-free animal room, had a higher total serum IgE level compared with mice living in a general animal room or farm house. These results suggest that exposure to an unsanitary environment improves immune function, possibly by increasing the diversity and richness of the gut microbiome (Zhou et al. 2016).

Endotoxins are lipopolysaccharides (LPS) from the cell wall of Gram-negative bacteria. Children's mattresses in farm 
areas had a higher endotoxin concentration than those from non-farming areas (Mutius et al. 2010). LPS can activate Th1type immune responses and interfere with the development of a Th2-type immune response while it also has a tendency to stimulate the Treg cell numbers and function (Martinez 1999; van Oosterhout and Bloksma 2005). The endotoxin from house dust can interact with genetic factors and modify the risk of atopic asthma (Zhang et al. 2008). Exposure to a high endotoxin concentration is associated with a reduced risk of allergic sensitization, while the risk of non-atopic wheeze increased in children with the CC genotype at -159 of the CD14 gene (Simpson et al. 2006). CD14 is part of the receptor complex for LPS and has been mapped to a locus on chromosome $5 \mathrm{q} 31.1$, which is linked to atopy and asthma (Goyert et al. 1988; Marsh et al. 1994; Pugin et al. 1994). Activation of this pathway results in a strong interleukin (IL)-12 expression in early life, which favors Th1 differentiation of naive T cells and reduces the probability of an $\mathrm{IgE}$ response to allergens (Trinchieri et al. 1992). The interaction of the genetic variants in the CD14 gene and endotoxin exposure has been known for several years and the hypothesis of endotoxin switch was proposed (Kabesch 2006; Vercelli 2003). There is a dosedependent relationship between environmental exposure to endotoxin and the outcome of immune responses which is not linear but bimodal with a switch that occurs from Th2 to Th1 responses (Vercelli 2003).

\section{Conclusion and Future Directions}

The house dust microbiome is affected by both outdoor and indoor environments as well as the occupants and their pets. The variation and diversity of the fungal community are mainly influenced by outdoor environmental factors including season and several indoor factors such as dampness and water leakage. In contrast, the variation and diversity of the bacterial community are significantly affected by occupants' activities, domestic environments, and ventilation methods. The number of occupants and the type of floor are significantly associated with bacterial diversity (Weikl et al. 2016). The house dust microbiome influences the host microbiome. For example, oral supplementation by Lactobacillus johnsonii can mediate airway protection and impact the gastrointestinal microbiome composition (Fujimura et al. 2014). Animal studies have consistently indicated that environmental exposure to microorganisms has a moderating effect on the intestinal microbiome. House dust exposure may also influence the function of our genome that determines immune balance and tolerance, for example, the switch hypothesis of endotoxin exposure and CD14. Airborne dust is the primary source of environmental agents and the response of the human immune system to airborne dust requires a long-term exposure (Sing and Sing 2010). Microbiome richness and diversity varies hugely in house dust. These variations in the domestic environment are indisputably related to human health and the allergic conditions highlighted in the present review. However, the mechanisms of how the environmental microbiomes, including house dust microbes, interact with the host microbiome and the human immune system are still poorly understood.

The present studies showed that house dust is an important source of exposure to environmental microorganisms and house dust microbiota is a key modulator of immune metabolic and cellular functions that responds to inflammatory signals associated with human disease. However, further efforts are needed to examine the specific mechanisms by which house dust microbial exposure and colonization on host to mediate their influence on disease. Though most studies used 16S rRNA gene amplicon sequencing to detect house dust microbiome, a culture-based method is still necessary to identify and isolate some specific bacteria species associated with disease. In addition, both epidemiological and experimental approaches are needed to further elucidate the role of the house dust microbiome in human health, and clinical observation is also important to the development of new microbiota-targeting therapies and diagnostics.

\section{Compliance with Ethical Standards}

Conflict of Interest The authors declare that they have no conflict of interest.

Publisher's note Springer Nature remains neutral with regard to jurisdictional claims in published maps and institutional affiliations.

\section{References}

Adams RI, Miletto M, Taylor JW, Bruns TD (2013) Dispersal in microbes: fungi in indoor air are dominated by outdoor air and show dispersal limitation at short distances. ISME J 7:1262-1273. https:// doi.org/10.1038/ismej.2013.28

Adams RI, Miletto M, Lindow SE, Taylor JW, Bruns TD (2014) Airborne bacterial communities in residences: similarities and differences with fungi. PLoS One 9:e91283. https://doi.org/10.1371/journal. pone.0091283

Adhikari A, Kettleson EM, Vesper S, Kumar S, Popham DL, Schaffer C, Indugula R, Chatterjee K, Allam KK, Grinshpun SA, Reponen T (2014) Dustborne and airborne Gram-positive and Gram-negative bacteria in high versus low ERMI homes. Sci Total Environ 482483:92-99. https://doi.org/10.1016/j.scitotenv.2014.02.110

Alenius H, Pakarinen J, Saris O, Andersson MA, Leino M, Sirola K, Majuri ML, Niemelä J, Matikainen S, Wolff H, von Hertzen L, Mäkelä M, Haahtela T, Salkinoja-Salonen M (2009) Contrasting immunological effects of two disparate dusts - preliminary observations. Int Arch Allergy Immunol 149:81-90

Amend AS, Seifert KA, Samson R, Bruns TD (2010) Indoor fungal composition is geographically patterned and more diverse in temperate zones than in the tropics. Proc Natl Acad Sci U S A 107: 13748-13753. https://doi.org/10.1073/pnas.1000454107

Andersen B, Frisvad JC, Sondergaard I, Rasmussen IS, Larsen LS (2011) Associations between fungal species and water-damaged building 
materials. Appl Environ Microbiol 77:4180-4188. https://doi.org/ 10.1128/Aem.02513-10

Andersson AM, Weiss N, Rainey F, Salkinoja-Salonen MS (1999) Dustborne bacteria in animal sheds, schools and children's day care centres. J Appl Microbiol 86:622-634. https://doi.org/10.1046/j.13652672.1999.00706.x

Ayerst G (1969) The effects of moisture and temperature on growth and spore germination in some fungi. J Stored Prod Res 5:127-141. https://doi.org/10.1016/0022-474X(69)90055-1

Barberan A et al (2015a) The ecology of microscopic life in household dust. Proc Biol Sci 282:20151139. https://doi.org/10.1098/rspb. 2015.1139

Barberan A, Ladau J, Leff JW, Pollard KS, Menninger HL, Dunn RR, Fierer N (2015b) Continental-scale distributions of dust-associated bacteria and fungi. Proc Natl Acad Sci U S A 112:5756-5761. https://doi.org/10.1073/pnas.1420815112

Beguin H (1995) Mould biodiversity in homes II. Analysis of mattress dust. Aerobiologia 11:3-10. https://doi.org/10.1007/bf02136138

Beguin H, Nolard N (1996) Prevalence of fungi in carpeted floor environment: analysis of dust samples from living-rooms, bedrooms, offices and school classrooms. Aerobiologia 12:113-120. https:// doi.org/10.1007/bf02446603

Bouillard L, Michel O, Dramaix M, Devleeschouwer M (2005) Bacterial contamination of indoor air, surfaces, and settled dust, and related dust endotoxin concentrations in healthy office buildings. Ann Agric Environ Med 12:187-192

Braun-Fahrlander C et al (2002) Environmental exposure to endotoxin and its relation to asthma in school-age children. N Engl J Med 347: 869-877. https://doi.org/10.1056/Nejmoa020057

Chen YS, Jan RL, Lin YL, Chen HH, Wang JY (2010) Randomized placebo-controlled trial of lactobacillus on asthmatic children with allergic rhinitis. Pediatr Pulmonol 45:1111-1120. https://doi.org/10. 1002/ppul.21296

Dannemiller KC, Mendell MJ, Macher JM, Kumagai K, Bradman A, Holland N, Harley K, Eskenazi B, Peccia J (2014) Nextgeneration DNA sequencing reveals that low fungal diversity in house dust is associated with childhood asthma development. Indoor Air 24:236-247. https://doi.org/10.1111/ina.12072

Dannemiller KC, Gent JF, Leaderer BP, Peccia J (2016) Influence of housing characteristics on bacterial and fungal communities in homes of asthmatic children. Indoor Air 26:179-192. https://doi. org/10.1111/ina. 12205

Dannemiller KC, Weschler CJ, Peccia J (2017) Fungal and bacterial growth in floor dust at elevated relative humidity levels. Indoor Air 27:354-363. https://doi.org/10.1111/ina.12313

Debarry J, Hanuszkiewicz A, Stein K, Holst O, Heine H (2010) The allergy-protective properties of Acinetobacter lwoffii F78 are imparted by its lipopolysaccharide. Allergy 65:690-697. https:// doi.org/10.1111/j.1398-9995.2009.02253.x

Douwes J, Zuidhof A, Doekes G, van der Zee S, Wouters I, Boezen HM, Brunekreef B (2000) (1 -> 3)-beta-D-glucan and endotoxin in house dust and peak flow variability in children. Am J Respir Crit Care Med 162:1348-1354. https://doi.org/10.1164/ajrccm.162.4. 9909118

Eder W, von Mutius E (2004) Hygiene hypothesis and endotoxin: what is the evidence? Curr Opin Allergy Clin Immunol 4:113-117

Ege MJ, Mayer M, Normand AC, Genuneit J, Cookson WOCM, BraunFahrländer C, Heederik D, Piarroux R, von Mutius E (2011) Exposure to environmental microorganisms and childhood asthma. N Engl J Med 364:701-709. https://doi.org/10.1056/ NEJMoa1007302

Ege MJ, Mayer M, Schwaiger K, Mattes J, Pershagen G, van Hage M, Scheynius A, Bauer J, von Mutius E (2012) Environmental bacteria and childhood asthma. Allergy 67:1565-1571. https://doi.org/10. 1111/all.12028
Fujimura KE et al (2010) Man's best friend? The effect of pet ownership on house dust microbial communities. J Allergy Clin Immunol 126: 410-412, 412 e411-413. https://doi.org/10.1016/j.jaci.2010.05.042

Fujimura KE, Demoor T, Rauch M, Faruqi AA, Jang S, Johnson CC, Boushey HA, Zoratti E, Ownby D, Lukacs NW, Lynch SV (2014) House dust exposure mediates gut microbiome lactobacillus enrichment and airway immune defense against allergens and virus infection. Proc Natl Acad Sci U S A 111:805-810. https://doi.org/10. 1073/pnas. 1310750111

Gliniewicz A et al (2003) German cockroaches (Blattella Germanica L.) as a potential source of pathogens causing nosocomial infections. Indoor Built Environ. https://doi.org/10.1177/ 1420326x03012001009

Goyert SM, Ferrero E, Rettig WJ, Yenamandra AK, Obata F, Le Beau MM (1988) The CD14 monocyte differentiation antigen maps to a region encoding growth factors and receptors. Science 239:497-500

Hanski I, von Hertzen L, Fyhrquist N, Koskinen K, Torppa K, Laatikainen T, Karisola P, Auvinen P, Paulin L, Makela MJ, Vartiainen E, Kosunen TU, Alenius H, Haahtela T (2012) Environmental biodiversity, human microbiota, and allergy are interrelated. Proc Natl Acad Sci U S A 109:8334-8339. https://doi. org/10.1073/pnas.1205624109

Hanson B, Zhou Y, Bautista EJ, Urch B, Speck M, Silverman F, Muilenberg M, Phipatanakul W, Weinstock G, Sodergren E, Gold DR, Sordillo JE (2016) Characterization of the bacterial and fungal microbiome in indoor dust and outdoor air samples: a pilot study. Environ Sci Processes Impacts 18:713-724. https://doi.org/10.1039/ $\mathrm{c} 5 \mathrm{em} 00639 \mathrm{~b}$

Heldal KK, Halstensen AS, Thorn J, Eduard W, Halstensen TS (2003) Airway inflammation in waste handlers exposed to bioaerosols assessed by induced sputum. Eur Respir J 21:641-645

Hospodsky D, Qian J, Nazaroff WW, Yamamoto N, Bibby K, RismaniYazdi H, Peccia J (2012) Human occupancy as a source of indoor airborne bacteria. PLoS One 7:e34867. https://doi.org/10.1371/ journal.pone. 0034867

Hospodsky D, Yamamoto N, Nazaroff WW, Miller D, Gorthala S, Peccia $\mathrm{J}$ (2015) Characterizing airborne fungal and bacterial concentrations and emission rates in six occupied children's classrooms. Indoor Air 25:641-652. https://doi.org/10.1111/ina. 12172

Iossifova YY, Reponen T, Bernstein DI, Levin L, Kalra H, Campo P, Villareal M, Lockey J, Hershey GKK, LeMasters G (2007) House dust (1-3)-beta-D-glucan and wheezing in infants. Allergy 62:504 513. https://doi.org/10.1111/j.1398-9995.2007.01340.x

Jaakkola JJK, Hwang BF, Jaakkola MS (2010) Home dampness and molds as determinants of allergic rhinitis in childhood: a 6-year, population-based cohort study. Am J Epidemiol 172:451-459. https://oi.org/10.1093/aje/kwq110

Kaarakainen P, Rintala H, Vepsalainen A, Hyvarinen A, Nevalainen A, Meklin T (2009) Microbial content of house dust samples determined with qPCR. Sci Total Environ 407:4673-4680. https://doi. org/10.1016/j.scitotenv.2009.04.046

Kabesch M (2006) A glitch in the switch? Of endotoxin, CD14, and allergy. Am J Respir Crit Care Med 174:365-366. https://doi.org/ 10.1164/rccm.2604006

Karvala K, Toskala E, Luukkonen R, Lappalainen S, Uitti J, Nordman H (2010) New-onset adult asthma in relation to damp and moldy workplaces. Int Arch Occup Environ Health 83:855-865. https://doi.org/ 10.1007/s00420-010-0507-5

Kembel SW, Jones E, Kline J, Northcutt D, Stenson J, Womack AM, Bohannan BJM, Brown GZ, Green JL (2012) Architectural design influences the diversity and structure of the built environment microbiome. ISME J 6:1469-1479. https://doi.org/10.1038/ismej. 2011.211

Khoo SK, Mäkelä M, Chandler D, Schultz EN, Jamieson SE, Goldblatt J, Haahtela T, LeSouëf P, Zhang G (2016) No simple answers for the Finnish and Russian Karelia allergy contrast: methylation of CD14 
gene. Pediatr Allergy Immunol 27:721-727. https://doi.org/10.1111/ pai. 12612

Korpi A, Pasanen AL, Pasanen P, Kalliokoski P (1997) Microbial growth and metabolism in house dust. Int Biodeterior Biodegrad 40:19-27

Korthals M, Ege M, Lick S, von Mutius E, Bauer J (2008) Occurrence of Listeria spp. in mattress dust of farm children in Bavaria. Environ Res 107:299-304. https://doi.org/10.1016/j.envres.2008.02.007

Laubach CA (1916) Spore-bearing bacteria in dust. J Bacteriol 1:493

Macher JM (2001) Review of methods to collect settled dust and isolate culturable microorganisms. Indoor Air 11:99-110

Marsh DG, Neely J, Breazeale D, Ghosh B, Freidhoff L, Ehrlich-Kautzky E, Schou C, Krishnaswamy G, Beaty T (1994) Linkage analysis of IL4 and other chromosome 5q31.1 markers and total serum immunoglobulin E concentrations. Science 264:1152-1156

Martinez FD (1999) Maturation of immune responses at the beginning of asthma. J Allergy Clin Immunol 103:355-361. https://doi.org/10. 1016/S0091-6749(99)70456-2

Mckinney ML (2006) Urbanization as a major cause of biotic homogenization. Biol Conserv 127:247-260

Meadow JF, Altrichter AE, Kembel SW, Kline J, Mhuireach G, Moriyama M, Northcutt D, O'Connor TK, Womack AM, Brown GZ, Green JL, Bohannan BJM (2014) Indoor airborne bacterial communities are influenced by ventilation, occupancy, and outdoor air source. Indoor Air 24:41-48. https://doi.org/10.1111/ina.12047

Moschandreas DJ, Pagilla KR, Storino LV (2003) Time and space uniformity of indoor bacteria concentrations in Chicago area residences. Aerosol Sci Technol 37:899-906. https://doi.org/10.1080/ 02786820300935

Mutius V et al (2010) Exposure to endotoxin or other bacterial components might protect against the development of atopy. Clin Exp Allergy 30:1230-1234

Nevalainen A, Taubel M, Hyvarinen A (2015) Indoor fungi: companions and contaminants. Indoor Air 25:125-156. https://doi.org/10.1111/ ina. 12182

Noris F, Siegel JA, Kinney KA (2011) Evaluation of HVAC filters as a sampling mechanism for indoor microbial communities. Atmos Environ 45:338-346. https://doi.org/10.1016/j.atmosenv.2010.10. 017

Pakarinen J, Hyvärinen A, Salkinoja-Salonen M, Laitinen S, Nevalainen A, Mäkelä MJ, Haahtela T, von Hertzen L (2008) Predominance of Gram-positive bacteria in house dust in the low-allergy risk Russian Karelia. Environ Microbiol 10:3317-3325. https://doi.org/10.1111/ j.1462-2920.2008.01723.x

Pitkaranta M, Meklin T, Hyvarinen A, Paulin L, Auvinen P, Nevalainen A, Rintala H (2008) Analysis of fungal flora in indoor dust by ribosomal DNA sequence analysis, quantitative PCR, and culture. Appl Environ Microbiol 74:233-244. https://doi.org/10.1128/AEM. 00692-07

Pitkaranta M et al (2011) Molecular profiling of fungal communities in moisture damaged buildings before and after remediation-a comparison of culture-dependent and culture-independent methods. BMC Microbiol 11:235. https://doi.org/10.1186/1471-2180-11-235

Pugin J et al (1994) Cd14 is a pattern-recognition receptor. Immunity 1 : 509-516. https://doi.org/10.1016/1074-7613(94)90093-0

Raison CL, Lowry CA, Rook GA (2010) Inflammation, sanitation, and consternation: loss of contact with coevolved, tolerogenic microorganisms and the pathophysiology and treatment of major depression. Arch Gen Psychiatry 67:1211-1224. https://doi.org/10.1001/ archgenpsychiatry.2010.161

Riedler J, Eder W, Oberfeld G, Schreuer M (2000) Austrian children living on a farm have less hay fever, asthma and allergic sensitization. Clin Exp Allergy 30:194-200

Riedler J, Braun-Fahrländer C, Eder W, Schreuer M, Waser M, Maisch S, Carr D, Schierl R, Nowak D, von Mutius E (2001) Exposure to farming in early life and development of asthma and allergy: a cross-sectional survey. Lancet 358:1129-1133. https://doi.org/10. 1016/S0140-6736(01)06252-3

Rintala H, Pitkaranta M, Toivola M, Paulin L, Nevalainen A (2008) Diversity and seasonal dynamics of bacterial community in indoor environment. BMC Microbiol 8:56. https://doi.org/10.1186/14712180-8-56

Rintala H, Pitkaranta M, Taubel M (2012) Microbial communities associated with house dust. Adv Appl Microbiol 78:75-120. https://doi. org/10.1016/B978-0-12-394805-2.00004-X

Rook GA, Martinelli R, Brunet LR (2003) Innate immune responses to mycobacteria and the downregulation of atopic responses. Curr Opin Allergy Clin Immunol 3:337-342. https://doi.org/10.1097/ 01.all.0000092602.76804.ad

Round JL, Lee SM, Li J, Tran G, Jabri B, Chatila TA, Mazmanian SK (2011) The Toll-like receptor 2 pathway establishes colonization by a commensal of the human microbiota. Science 332:974-977. https://doi.org/10.1126/science.1206095

Rylander R, Holt PG (1998) (1->3)-beta-D-glucan and endotoxin modulate immune response to inhaled allergen. Mediat Inflamm 7:105110. https://doi.org/10.1080/09629359891252

Sharpe RA, Bearman N, Thornton CR, Husk K, Osborne NJ (2015) Indoor fungal diversity and asthma: a meta-analysis and systematic review of risk factors. J Allergy Clin Immunol 135:110-122. https:// doi.org/10.1016/j.jaci.2014.07.002

Simpson A, John SL, Jury F, Niven R, Woodcock A, Ollier WER, Custovic A (2006) Endotoxin exposure, CD14, and allergic disease - an interaction between genes and the environment. Am J Respir Crit Care Med 174:386-392. https://doi.org/10.1164/rccm.200509$1380 \mathrm{OC}$

Sing D, Sing CF (2010) Impact of direct soil exposures from airborne dust and geophagy on human health. Int J Environ Res Public Health 7:1205-1223. https://doi.org/10.3390/ijerph7031205

Sokol H, Pigneur B, Watterlot L, Lakhdari O, Bermudez-Humaran LG, Gratadoux JJ, Blugeon S, Bridonneau C, Furet JP, Corthier G, Grangette C, Vasquez N, Pochart P, Trugnan G, Thomas G, Blottiere HM, Dore J, Marteau P, Seksik P, Langella P (2008) Faecalibacterium prausnitzii is an anti-inflammatory commensal bacterium identified by gut microbiota analysis of Crohn disease patients. Proc Natl Acad Sci U S A 105:16731-16736. https://doi. org $/ 10.1073 /$ pnas.0804812105

Spor A, Koren O, Ley R (2011) Unravelling the effects of the environment and host genotype on the gut microbiome. Nat Rev Microbiol 9:279-290. https://doi.org/10.1038/nrmicro2540

Strachan DP (1989) Hay fever, hygiene, and household size. BMJ 299: $1259-1260$

Taubel M et al (2009) The occupant as a source of house dust bacteria. J Allergy Clin Immunol 124:834-840 e847. https://doi.org/10.1016/j. jaci.2009.07.045

Thorn J (2001) Seasonal variations in exposure to microbial cell wall components among household waste collectors. Ann Occup Hyg 45:153-156. https://doi.org/10.1016/S0003-4878(00)00056-9

Torvinen E, Torkko P, Rintala AN (2010) Real-time PCR detection of environmental mycobacteria in house dust. J Microbiol Methods 82: 78-84. https://doi.org/10.1016/j.mimet.2010.04.007

Trinchieri G et al (1992) Natural killer cell stimulatory factor (NKSF) or interleukin-12 is a key regulator of immune response and inflammation. Prog Growth Factor Res 4:355-368

van Oosterhout AJM, Bloksma N (2005) Regulatory T-lymphocytes in asthma. Eur Respir J 26:918-932. https://doi.org/10.1183/ 09031936.05.00011205

Vercelli D (2003) Learning from discrepancies: CD14 polymorphisms, atopy and the endotoxin switch. Clin Exp Allergy 33:153-155

Vo N, Tsai TC, Maxwell C, Carbonero F (2017) Early exposure to agricultural soil accelerates the maturation of the early-life pig gut microbiota. Anaerobe 45:31-39. https://doi.org/10.1016/j.anaerobe. 2017.02.022 
Von HL, Hyvärinen A, Laatikainen T, Mäkelä MJ, Nevalainen A, Vartiainen E, Haahtela T (2010) Risk of atopy associated with microbial components in house dust. Ann Allergy Asthma Immunol 104:269-270

Weikl F, Tischer C, Probst AJ, Heinrich J, Markevych I, Jochner S, Pritsch K (2016) Fungal and bacterial communities in indoor dust follow different environmental determinants. PLoS One 11: e0154131. https://doi.org/10.1371/journal.pone.0154131

Wickman M, Gravesen S, Nordvall SL, Pershagen G, Sundell J (1992) Indoor viable dust-bound microfungi in relation to residential characteristics, living habits, and symptoms in atopic and control children. J Allergy Clin Immunol 89:752-759. https://doi.org/10.1016/ 0091-6749(92)90384-E

Wouters IM, Hilhorst SKM, Kleppe P, Doekes G, Douwes J, Peretz C, Heederik D (2002) Upper airway inflammation and respiratory symptoms in domestic waste collectors. Occup Environ Med 59: 106-112. https://doi.org/10.1136/Oem.59.2.106

Yamamoto N, Shendell DG, Peccia J (2011) Assessing allergenic fungi in house dust by floor wipe sampling and quantitative PCR. Indoor Air 21:521-530. https://doi.org/10.1111/j.16000668.2011.00732.x

Zhang G, Goldblatt J, LeSouef PN (2008) Does the relationship between $\mathrm{IgE}$ and the CD14 gene depend on ethnicity? Allergy 63:14111417. https://doi.org/10.1111/j.1398-9995.2008.01804.x

Zhou D, Zhang H, Bai Z, Zhang A, Bai F, Luo X, Hou Y, Ding X, Sun B, Sun X, Ma N, Wang C, Dai X, Lu Z (2016) Exposure to soil, house dust and decaying plants increases gut microbial diversity and decreases serum immunoglobulin E levels in BALB/c mice. Environ Microbiol 18:1326-1337. https://doi.org/10.1111/1462-2920.12895 